\title{
Gambaran status kebersihan gigi dan mulut di Panti Asuhan Nazaret Tomohon
}

\author{
${ }^{1}$ Maya P. Mangowal \\ ${ }^{2}$ Damajanty H. C. Pangemanan \\ ${ }^{3}$ Christy N. Mintjelungan
}

\author{
${ }^{1}$ Kandidat Skripsi Program Studi Pendidikan Dokter Gigi Fakultas Kedokteran \\ ${ }^{2}$ Bagian Fisiologi Fakultas Kedokteran \\ ${ }^{3}$ Program Studi Pendidikan Dokter Gigi Fakultas Kedokteran \\ Universitas Sam Ratulangi Manado \\ Email: maya_patrisia@yahoo.com
}

\begin{abstract}
Dental and oral health is important for every individual. It plays an important role in the prevention of caries. During growth and development periods, adolescents often have health problems; one of them is oral and dental hygiene. This study was aimed to obtain the profile of oral and dental hygiene status among adolescents at Panti Asuhan Nazaret (an orphanage) Tomohon. This was a descriptive study with a cross sectional design using total sampling method. There were 37 adolescents as respondents. The results showed that $59.5 \%$ of them belonged to good category, $32.4 \%$ to moderate category, and $8.1 \%$ to poor category. Conclusion: The oral and dental hygiene status of most adolescents at Panti Asuhan Nazaret Tomohon was in good category. However, education and counseling about the importance of oral and dental hygiene are still needed.
\end{abstract}

Keywords: dental and mouth hygiene, adolescents

\begin{abstract}
Abstrak: Kesehatan gigi dan mulut penting diketahui tiap individu. Hal tersebut sangat berperan dalam upaya pencegahan terjadinya karies. Dalam pertumbuhan dan perkembangan, remaja sering mengalami masalah kesehatan, salah satunya masalah kebersihan gigi dan mulut. Penelitian ini bertujuan untuk mengetahui gambaran status kebersihan gigi dan mulut pada anak remaja di Panti Asuhan Nazaret Tomohon. Jenis penelitian ialah deskriptif dengan desain potong lintang. Metode pengambilan sampel ialah total sampling. Jumlah responden dalam penelitian ini ialah 37 anak remaja. Hasil penelitian menunjukkan bahwa status kebersihan gigi dan mulut dari 59,5\% responden termasuk kategori baik, 32,4\% kategori sedang, dan 8,1\% kategori buruk. Simpulan: Gambaran status kebersihan gigi dan mulut sebagian besar anak remaja di Panti Asuhan Nazaret Tomohon termasuk dalam kategori baik. Disarankan untuk diberikan pendidikan dan penyuluhan tentang pentingnya menjaga kebersihan gigi dan mulut.
\end{abstract}

Kata kunci: kebersihan gigi dan mulut, remaja

Kesehatan gigi dan mulut merupakan bagian dari kesehatan tubuh yang tidak dapat dipisahkan satu dan lainnya karena akan memengaruhi kesehatan tubuh secara keseluruhan. Gigi berperan penting dalam proses pengunyahan, berbicara, dan mempertahankan bentuk muka sehingga adanya masalah pada gigi akan dapat menganggu fungsi atau peran gigi. ${ }^{1}$

Data hasil Riset Kesehatan Dasar (RISKESDAS) tahun 2013 yang di keluarkan Departemen Kesehatan RI melaporkan bahwa prevalensi masalah gigi dan mulut penduduk Indonesia mencapai $25,9 \%$. Hasil tersebut menunjukkan bahwa terjadi peningkatan prevalensi masalah gigi 
dan mulut sebesar $2,7 \%$ bila dibandingkan dengan hasil RISKESDAS tahun 2007. Berdasarkan data Dinas kesehatan tahun 2013, Sulawesi Utara diperkirakan memiliki 57\% karies aktif di usia 15 tahun ke atas. ${ }^{1}$

Kebersihan gigi dan mulut di Indonesia perlu diperhatikan, karena penyakit gigi dan mulut merupakan penyakit yang dikeluhkan oleh masyarakat. Anak merupakan usia rentan terhadap penyakit gigi dan mulut karena masih memerlukan bantuan dari orang tua maupun keluarga untuk membimbingnya dalam menjaga kebersihan gigi dan mulut. ${ }^{2}$

Kesadaran terhadap kebersihan mulut pada anak-anak sangat rendah yang diakibatkan karena kurangnya pendidikan dan kemampuan anak-anak dalam menjaga kebersihan gigi dan mulut. ${ }^{3}$ Salah satu penyebab timbulnya masalah kesehatan gigi dan mulut pada masyarakat ialah faktor perilaku atau sikap mengabaikan kebersihan gigi dan mulut. Selain itu, pembinaan kesehatan gigi terutama pada anak usia sekolah perlu mendapat perhatian khusus karena pada usia ini anak sedang menjalani proses tumbuh kembang, dan masih sangat bergantung kepada orang dewasa dalam hal menjaga kesehatan dan kebersihan gigi. Keadaan gigi sebelumnya akan berpengaruh terhadap perkembangan kesehatan gigi selanjutnya seperti gigi susu yang terkena karies akan memengaruhi pertumbuhan gigi permanen nantinya.,

Dalam survei awal di Panti Asuhan Nazaret Tomohon sebagian anak remaja memiliki masalah kesehatan gigi. Berdasarkan latar belakang tersebut peneliti ingin mengetahui gambaran status kebersihan gigi dan mulut di Panti Asuhan tersebut.

\section{BAHAN DAN METODE PENELITIAN}

Jenis penelitian ini ialah deskriptif dengan desain potong lintang. Penelitian dilakukan di Panti Asuhan Nazaret Tomohon pada bulan Juli 2017. Populasi dalam penelitian ini ialah anak-anak penghuni Panti Asuhan Nazaret Tomohon, berjumlah 37 orang. Kriteria inklusi ialah remaja berusia 10-20 tahun di Panti Asuhan Nazaret Tomohon yang bersedia dengan sukarela dan atas izin kepala panti asuhan untuk dijadikan responden penelitian ini; bersifat kooperatif selama pengambilan data; dapat berkomunikasi dengan baik; dan tinggal tetap di panti asuhan. Pengambilan sampel dilakukan dengan total sampling.

Pemeriksaan indeks debris dan kalkulus dilakukan pada permukaan elemen gigi rahang atas yang diperiksa yaitu gigi M1 kanan atas pada permukaan bukal, gigi I1 kanan atas pada permukaan labial, dan gigi M1 kiri atas pada permukaan bukal. Elemen gigi rahang bawah yang diperiksa yaitu gigi M1 kiri bawah pada permukaan lingual, gigi I1 kiri bawah pada permukaan labial, gigi M1 kanan bawah pada permukaan lingual menggunakan kaca mulut dan sonde. Pasien berkumur selama 10 detik. Penghitungan indeks debris dan indeks kalkulus digunakan untuk pengukuran oral hygiene index simplified (OHI-S). Status kebersihan gigi dan mulut diukur berdasarkan OHI-S menurut WHO dengan menjumlahkan debris index simplified (DI-S) dan calculus index simplified (CI-S). ${ }^{5,6}$ Data yang telah dikumpulkan kemudian diolah dengan cara manual dan dihitung persentasenya kemudian disajikan dalam bentuk tabel distribusi frekuensi dan analisis.

\section{HASIL PENELITIAN}

Hasil penelitian diperoleh melalui pemeriksaan kebersihan gigi dan mulut, berdasarkan jenis kelamin dan usia.

Tabel 1. Distribusi responden berdasarkan jenis kelamin

\begin{tabular}{lcc}
\hline Jenis kelamin & $(\mathrm{n})$ & $(\%)$ \\
\hline Laki-laki & 22 & 59,5 \\
Perempuan & 15 & 40,5 \\
Jumlah & 37 & 100 \\
\hline
\end{tabular}


Tabel 2. Distribusi responden berdasarkan usia

\begin{tabular}{ccc}
\hline $\begin{array}{c}\text { Usia } \\
\text { (tahun) }\end{array}$ & (n) & $(\boldsymbol{\%})$ \\
\hline $10-11$ & 11 & 29,73 \\
$12-13$ & 7 & 18,91 \\
$14-15$ & 8 & 21,62 \\
$16-17$ & 5 & 13,51 \\
$18-20$ & 6 & 16,23 \\
Jumlah & 37 & 100 \\
\hline
\end{tabular}

Tabel 3. Distribusi responden berdasarkan status OHI-S

\begin{tabular}{ccc}
\hline Status OHI-S & (n) & $\mathbf{( \% )}$ \\
\hline Baik & 22 & 59,5 \\
Sedang & 12 & 32,4 \\
Buruk & 3 & 8,1 \\
Jumlah & 37 & 100 \\
\hline
\end{tabular}

Tabel 4. Distribusi status kebersihan gigi dan mulut (OHI-S) berdasarkan jenis kelamin responden

\begin{tabular}{|c|c|c|c|c|c|c|c|c|}
\hline \multirow{3}{*}{$\begin{array}{c}\text { Jenis } \\
\text { kelamin }\end{array}$} & \multicolumn{6}{|c|}{ Kategori OHI-S } & \multirow{2}{*}{\multicolumn{2}{|c|}{ Jumlah }} \\
\hline & \multicolumn{2}{|c|}{ Baik } & \multicolumn{2}{|c|}{ Sedang } & \multicolumn{2}{|c|}{ Buruk } & & \\
\hline & $\mathrm{n}$ & $\%$ & $\mathrm{n}$ & $\%$ & $\mathrm{~N}$ & $\%$ & $\mathrm{n}$ & $\%$ \\
\hline Laki-laki & 12 & 32,4 & 8 & 21,6 & 2 & 5,4 & 22 & 59,5 \\
\hline Perempuan & 10 & 27,1 & 4 & 10,8 & 1 & 2,7 & 15 & 40,5 \\
\hline Jumlah & 22 & 59,5 & 12 & 32,4 & 3 & 8,1 & 37 & 100 \\
\hline
\end{tabular}

Tabel 5. Distribusi responden berdasarkan usia dan status OHI-S

\begin{tabular}{|c|c|c|c|c|c|c|c|c|}
\hline \multirow{3}{*}{ Usia } & \multicolumn{6}{|c|}{ Status OHI-S } & \multirow{2}{*}{\multicolumn{2}{|c|}{ Jumlah }} \\
\hline & \multicolumn{2}{|c|}{ Baik } & \multicolumn{2}{|c|}{ Sedang } & \multicolumn{2}{|c|}{ Buruk } & & \\
\hline & $\mathrm{n}$ & $\%$ & $\mathrm{n}$ & $\%$ & $\mathrm{n}$ & $\%$ & $\mathrm{n}$ & $\%$ \\
\hline $10-11$ & 4 & 10,8 & 5 & 13,5 & 2 & 5,4 & 11 & 29,7 \\
\hline $12-13$ & 4 & 10,8 & 2 & 5,4 & 1 & 2,7 & 7 & 18,9 \\
\hline $14-15$ & 6 & 16,2 & 2 & 5,4 & 0 & 0 & 8 & 21,7 \\
\hline $16-17$ & 3 & 8,1 & 2 & 5,4 & 0 & 0 & 5 & 13,5 \\
\hline $18-20$ & 5 & 13,6 & 1 & 2,7 & 0 & 0 & 6 & 16,2 \\
\hline Jumlah & 22 & 59,5 & 12 & 32,4 & 3 & 8,1 & 37 & 100 \\
\hline
\end{tabular}

\section{BAHASAN}

Responden yang didapat sebanyak 37 remaja dengan jumlah responden laki-laki sebanyak 22 orang dan responden perempuan sebanyak 15 orang. Berdasarkan jenis kelamin diperoleh hasil bahwa OHI-S pada responden laki-laki 32,4\% baik, 21,6\% sedang, dan 5,4\% buruk sedangkan pada responden perempuan $27,1 \%$ baik, $10,8 \%$ sedang, dan $2,7 \%$ buruk. Hasil ini tidak sejalan dengan penelitian yang dilakukan Babu et al. di India yang menyatakan bahwa kebersihan mulut pada anak perempuan lebih baik dibandingkan laki-laki karena anak perempuan lebih baik mempraktekkan prilaku menjaga kebersihan mulut

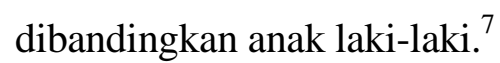

Tindakan menjaga kebersihan gigi dan mulut lebih dipengaruhi oleh pengetahuan yang dimiliki individu. Notoatmodjo ${ }^{8}$ menjelaskan bahwa penyebab timbulnya masalah kesehatan gigi dan mulut salah satunya ialah faktor perilaku atau sikap dan tindakan yang mengabaikan kebersihan gigi dan mulut. Hal tersebut dilandasi oleh kurangnya pengetahuan akan pentingnya pemeliharaan kebersihan gigi dan mulut.

Tingkat kebersihan gigi dan mulut dapat diperiksa dengan menggunakan (OHI-S). Pada OHI-S yang diperiksa ialah enam gigi yang telah diseleksi dan dianggap telah mewakili baik segmen anterior maupun segmen posterior dari 
seluruh gigi di dalam rongga mulut. ${ }^{5,6}$

Hasil penelitian berdasarkan usia memperlihatkan bahwa responden penelitian terbanyak berada di usia 10 dan 11 tahun yaitu 11 orang. Dari tingkat OHI$\mathrm{S}$, yang terbanyak ialah OHI-S kategori baik sebanyak 22 responden, OHI-S kategori sedang pada 12 responden, dan OHI-S kategori buruk pada 3 responden. Hasil penelitian ini tidak selaras dengan penelitian yang dilakukan oleh Lesar et al. ${ }^{9}$ di SMP Advent Watulaney yang melaporkan responden dengan status OHI$\mathrm{S}$ baik sebesar $3,17 \%$, responden dengan status OHI-S sedang 7,94\%, dan responden dengan kategori buruk 1,5\%. Hal seperti ini juga pernah di teliti Mawuntu et al. ${ }^{10}$ di SD Katolik St. Agustinus Kawangkoan yang menunjukkan hasil baik sebesar 36,92\%.

Penelitian ini menunjukkan hasil yang berbeda dengan penelitian lainnya, yaitu gambaran status kebersihan gigi dan mulut di Panti Asuhan Nazaret Tomohon 59,5\% termasuk kategori baik. Hasil ini di sebabkan Kepala Panti Asuhan dan pengasuh sudah mengajarkan cara menjaga kebersihan gigi dan mulut dan didapatkan anak remaja ini bisa menyikat gigi tanpa bantuan kepala panti asuhan dan pengasuh.

Dari hasil-hasil penelitian di atas, dapat dipahami bahwa kebutuhan akan perawatan kebersihan gigi dan mulut semakin meningkat. Para orang tua harus menanamkan kedisiplinan kepada anak dalam memelihara kebersihan gigi dan mulut sejak dini. Bila sejak dini anak terbiasa membersihkan gigi dan mulut,dia tidak akan memberontak saat di bawah ke dokter gigi. ${ }^{11}$

\section{SIMPULAN}

Kebersihan gigi dan mulut pada anak remaja di Panti Asuhan Nazaret Tomohon sebagian besar memiliki status OHI-S kategori baik.

\section{SARAN}

1. Perlu adanya kegiatan pemeriksaan rutin pada dokter gigi di Puskesmas karena masih ada anak yang kurang kesadaran dalam menjaga kebersihan gigi dan mulut.

2. Perlu diberikan pendidikan dan penyuluhan tentang pentingnya menjaga kebersihan gigi dan mulut minimal 6 bulan sekali.

\section{DAFTAR PUSTAKA}

1. Riskesdas. Riset kesehatan dasar Laporan Nasional Riskesdas 2013. Badan Penelitian dan Pengembangan Kesehatan Republik Indonesia. Available from: URL://www.Litbang.depkes go.id/Laporan RKD/Indonesia. 2013; p. 110-2.

2. Salmiah S. Reterdasi Mental. Medan: Departemen Ilmu Kedokteran Gigi Anak Fakultas Kedokteran Gigi USU, 2010; p. 14.

3. Pulu MA, Gunawan PN, Juliatri. Status kebersihan mulut dan kebiasaan menyikat gigi siswa SD GMIM Eben Haezar Kombos Manado. Dentire . 2012;1(2): 109.

4. Wedari S. Peran kebersihan rongga mulut pada pencegahan karies dan penyakit periodontal [Skripsi]. Surabaya: Universitas Airlangga; 2008.

5. WHO. 2007 OHI-S (Simplified) Green and Vermilion $1964 . \quad$ Available from:http://www.whocollab.od.mah.se /expl/ohisgv.html. 26 May 2010.

6. Bakar A. Kedokteran Gigi Klinis (2nd ed). Yogyakarta: Quantum Sinergis Media, 2013; p. 110-1.

7. Gopdianto R, Rattu AJM, Ni Wayan Mariati. Status kebersihan mulut dan perilaku menyikat gigi anak SD Negeri 1 Malalayang. eG. 2015;3(1):134.

8. Notoatmodjo S. Ilmu Perilaku Kesehatan. Jakarta: Rineka Cipta, 2010; p. 118.

9. Lesar AM. Gambaran status kebersihan gigi dan mulut serta status gingiva pada anak remaja di SMP Advent Watulaney Kabupaten Minahasa. eG. 2015;3(2):304.

10. Mawuntu MM. Gambaran status kebersihan mulut siswa SD Katholik St. Agustinus Kawangkoan. eG. 2015:3(2):255.

11. Sunarwati T, Kadim M. Retardasi Mental Ilmu Kesehatan Anak. Jakarta: FKUI, 2007; p. 170-7. 